\title{
A preliminary checklist of polypores of Peru, with notes on distribution in the Andes-Amazon region and new records for the country
}

\author{
Salvador-Montoya $\mathrm{CA}^{1,3^{*}}$, Millán $\mathrm{B}^{1}$, Janovec $\mathrm{JP}^{2}$ and Drechsler-Santos $\mathrm{ER}^{3}$ \\ ${ }^{1}$ Museo de Historia Natural, Universidad Nacional Mayor de San Marcos, Lima, Peru \\ ${ }^{2}$ Facultad de Ciencias Forestales, Herbario MOL, Universidad Nacional Agraria La Molina, Lima, Peru \\ ${ }^{3}$ Departamento de Botânica, Universidade Federal de Santa Catarina, Florianópolis, Brazil
}

Salvador-Montoya CA, Millán B, Janovec JP, Drechsler-Santos ER 2012 - A preliminary checklist of polypores of Peru, with notes on distribution in the Andes-Amazon region and new records for the country. Mycosphere 3(3), 282-287, Doi 10.5943/mycosphere/3/3/2

A checklist of 33 polypore species (Hymenochaetales and Polyporales) from the CamantiMarcapata Biological Corridor (CMBC) of Cusco, Peru, is provided with data about distribution in the Andes-Amazon region. More than $90 \%$ of polypore species reported herein are new records to the country.

Key words - Agaricomycetes - Amazon - Andes Mountains - Basidiomycota - cloud forest rainforest

\section{Article Information}

Received 10 April 2012

Accepted 12 April 2012

Published online 11 May 2012

*Corresponding author: Carlos Alberto Salvador Montoya - e-mail - csalvador05@gmail.com

\section{Introduction}

The Camanti-Marcapata Biological Corridor $(\mathrm{CMBC})$ is located in the southeastern corner of the department of Cusco, Peru, in the districts of Camanti and Marcapata, which encompass the headwater region of the Madre de Dios River watershed. The CMBC encompasses an area of 197,225.55 hectares located between 13.2$13.26^{\circ} \mathrm{S}$ and $70.77-70.54^{\circ} \mathrm{W}$ (Fig. 1) and ranges in elevation from $500-3500 \mathrm{msl}$. The area is characterized by extremely high precipitation up to $7,000 \mathrm{~mm}$ per year and an annual mean temperature of $25^{\circ} \mathrm{C}$. The typical vegetation of the area includes the upper limits of lowland Amazonian moist forest as well as Andean submontane and montane cloud forest. The area is difficult to access due to its rugged topography, dense vegetation, and heavy precipitation. Because of its pristine condition, the region has been the focus of planning aimed at the declaration of a regional conservation area. However, no mycodiversity studies of Basidiomycota fungi had ever been conducted in this region. Only recently, a new genus of freshwater fungi from submerged wood, Chaetorostratum quincemilensis Zelski, Raja, A.N. Mill \& Shearer (Zelski et al. 2011), was described from this area. The area is traversed by the recently constructed transamazonian, interoceanic highway and the principal threats include deforestation and a steady rise in gold mining. Botanical and mycological inventories were initiated in the region by authors Salvador and Janovec, and collaborators. The purpose of this paper is to present the first checklist of polypore fungi of the AndesAmazon region of south-eastern Peru.

\section{Material and methods}

This study is based on 102 specimens of polypore fungi collected in the CMBC during March-May, 2010. Macroscopic characters (shape, size, colour, type of pileus 

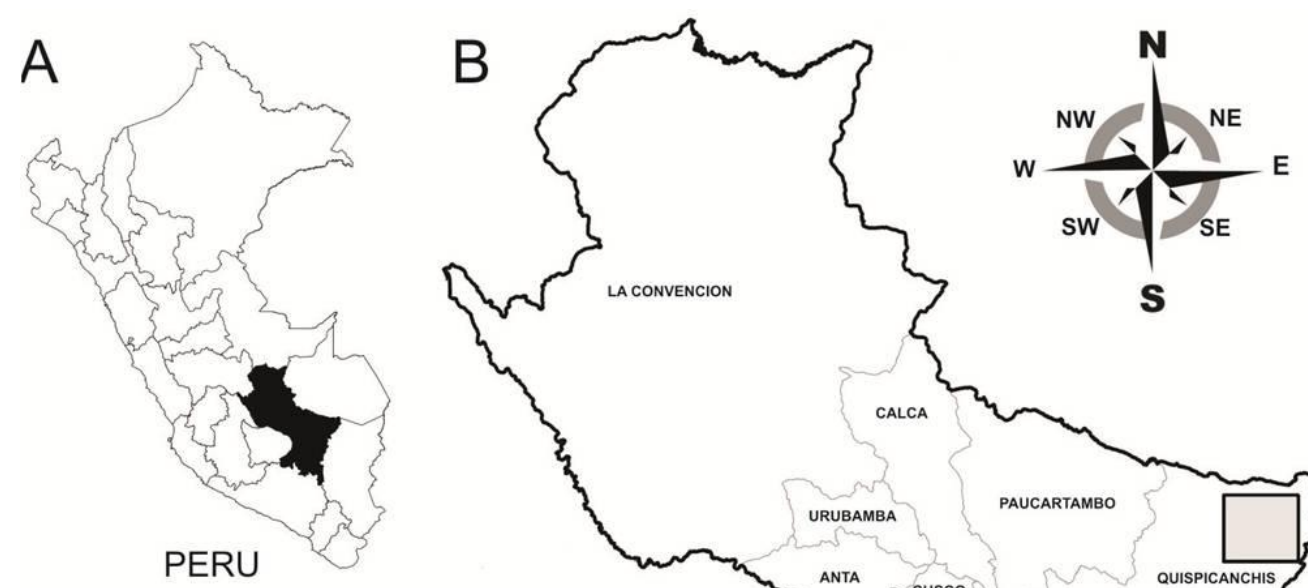

Marcapata-Camanti Biological Corridor

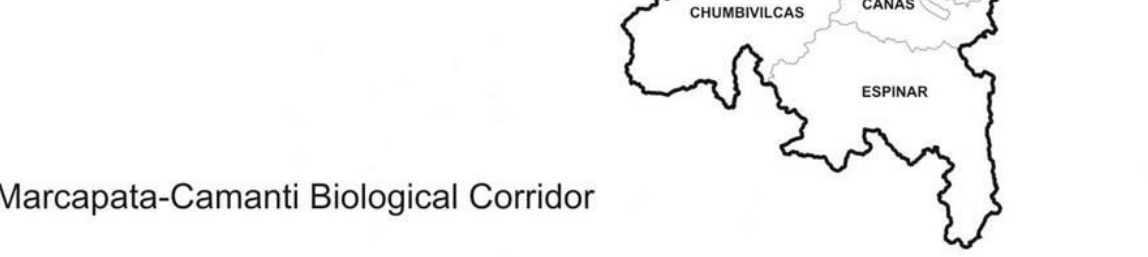

Fig. 1 - Location of the study area in the Camanti-Marcapata Biological Corridor (CMBC) in the Department of Cusco (B), Peru (A).

and hymenophore) and microscopic characters (presence/absence and dimensions of structures: sterile elements and basidiospores) (Ryvarden 1991) of basidiomata were analyzed and measurements were made from slide preparations stained with $1 \%$ aqueous phloxine and $3-5 \% \mathrm{KOH}$. Melzer's reagent was used to define wall chemical characteristics (dextrinoid or amyloid reaction). Specimens were identified to species using specialized literature and comparison with specimens in the Herbarium of the Universidade Federal de Santa Catarina (FLOR) of Florianópolis, Brazil. Nomenclatural and classification systems follow those of Hibbett et al. (2007), Index Fungorum (www.indexfungorum.org), and Centraalbureau voor Schimmelcultures (www.cbs.knaw.nl). Voucher specimens were deposited in the San Marcos Herbarium (USM) of Lima, Peru, and the FLOR Herbarium. Authorization for collections (RD 0202-2010AG-DGFFS-DGEFFS) and export permits (003923-AG-DGFSS) were granted by the Directorio General de Flora y Fauna Silvestre (DGFFS) of Peru.

\section{Results and discussion}

A total of 33 species of polypore fungi from the orders Hymenochaetales Oberw. and Polyporales Gäum. are reported from the CMBC of south-eastern Peru. Hymenochaetales is represented by five species $(15 \%$ of total) of Hymenochaetaceae in the following genera: Fuscoporia (2 species, $40 \%$ of the order), Fulvifomes with $F$. merrillii Phellinus with $P$. portoricensis, and Phylloporia with $P$. pectinata. All Hymenochaetales species represent new records for Peru. Polyporales was represented by 28 species ( $85 \%$ of total) belonging to the following families: Fomitopsidaceae with Fomitopsis lilacinogilva and $F$. nivosa, Ganodermataceae (7 species, $25 \%$ of the order), Meripilaceae with Henningsia brasiliensis and Rigidoporus microporus, Phanerochaetaceae with Antrodiella semisu-pina and Flaviporus hydrophilus, and Polypo-raceae (15 species, $54 \%$ of the order). Polyporaceae and Ganodermataceae were the most species-rich families reported in this study. Polyporaceae represented by Polyporus (6 species, 18\% of 
Mycosphere Doi 10.5943/mycosphere/3/3/2

total) and Trametes with T. versicolor and $T$. villosa (6\% of total). The remaining seven genera of the Polyporaceae were each represented by only one species. Ganodermataceae was represented by Amauroderma (4 species, $12 \%$ of total) and Ganoderma (3 species, $9 \%$ of total).

Seventeen species, $52 \%$ of total, have a pantropical distribution, 12 species $(36 \%$ of total) are neotropical and only four species (12\% of total) are cosmopolitan. The 33 species reported in this first checklist of the $\mathrm{CMBC}$ represent our current knowledge of the diversity and distribution of polypore fungi of the Andes-Amazon region of south-eastern Peru. In addition, 30 polypore species $(91 \%$ of total) of this work are new records for Peru. Future investigations will certainly increase the number of fungal records and expand the reported species ranges throughout the area.

List of polypore species of the CamantiMarcapata Biological Corridor of Cusco, Peru as follows:

Novelties in distribution are indicated

$(\boldsymbol{\square})=$ first record for Peru

( $\square)$ = first record for the department of

Cusco

\section{HYMENOCHAETALES}

Hymenochaetaceae Imazeki \& Toki

- Fulvifomes merrillii (Murrill) Baltazar \& Gibertoni

Specimens examined - Vitobamba (USM 239446).

Notes - probably a pantropical species, but rare (Larsen \& Cobb-Poulle 1990).

- Fuscoporia gilva (Schwein.) T. Wagner \& M. Fisch.

Specimens examined - Quincemil (USM 239435, 239467, 239434); Vitobamba (USM 239480); Capiri (USM 239448); Culebrachayoc (USM 239452); Marcapata (USM 239498).

Notes - pantropical species (Ryvarden 2004).

- Fuscoporia senex (Ness \& Mont) Ghob.-
Nejh.

Specimens examined - Quincemil (USM 239501).

Notes - pantropical species (Ryvarden 2004).

- Phellinus portoricensis (Overh.) O. Fidalgo Specimens examined: Quincemil (USM 239433).

Notes - neotropical species (Ryvarden 2004).

- Phylloporia pectinata (Kl.) Ryvarden

Specimens examined - Vitobamba (USM 239437).

Notes - neotropical species (Ryvarden 2004).

\section{POLYPORALES}

Fomitopsidaceae Jülich

- Fomitopsis lilacinogilva (Berk.) Wright \& Deschamp.

Specimens examined - Vitobamba (USM 239491).

Notes - pantropical species (Ryvarden \& Johansen 1980).

- Fomitopsis nivosa (Berk.) Gilbn. \& Ryv. Specimens examined - Quincemil (USM 239453).

Notes - neotropical species (Núñez \& Ryvarden 2001).

\section{Ganodermataceae Donk}

Amauroderma boleticeum (Pat. \& Gaillard) Torrend.

Specimens examined - Vitobamba (USM 239424, 239476, 251944).

Notes - neotropical species (Ryvarden 2004).

- Amauroderma coltricioides Aime, Henkel \& Ryvarden

Specimens examined - Vitobamba (USM 239423).

Notes - neotropical species (Ryvarden 2004).

Amauroderma partitum (Berk.) Wakef. 
Specimens examined - Vitobamba (USM 239429).

Notes - neotropical species (Ryvarden 2004).

$\square$ Amauroderma schomburgkii (Pat.) Torrend. Specimens examined - Vitobamba (USM 239431, 251946).

Notes - neotropical species (Ryvarden 2004), recorded in Peru by Furtado (1981) from Loreto (BPI) and San Martín (SP23157).

- Ganoderma australe (Fr.) Pat.

Specimens examined - Quincemil (USM 239422, 239425, 239426); Culebrachayoc (USM 239451).

Notes - pantropical species (Núñez \& Ryvarden 2000), common in the Neotropics (Ryvarden 2004).

\section{$\square$ Ganoderma coffeatum (Berk.) Furtado}

Specimen examined - Vitobamba (USM 239523).

Notes - neotropical species (Ryvarden 2004), recorded in Peru by Furtado (1967) from Loreto (BPI) and Navarro-Chipurana (BPI) (Decock \& Herrera-Figueroa 2007).

$\square$ Ganoderma stipitatum (Murrill) Murrill

Specimens examined - Vitobamba (USM 239427, 239428).

Notes - neotropical species (Ryvarden 2004), previously reported for Peru by Steyaert (1972), Corner (1983), and Ryvarden (2000). The specimen cited by Corner (1983) is from Loreto, Iquitos (Peru, Corner s.n. 7 April 1948 - on buried wood in the forest). The other authors do not mention the collection locality or herbarium specimen voucher.

\section{Meripilaceae Jülich}

- Henningsia brasiliensis (Speg.) Speg. Specimens examined - Vitobamba (USM 239477).

Notes - neotropical species (Núñez 1996).

- Rigidoporus microporus (Sw.) Overeem Specimens examined - Quincemil (USM 239456, 251952, 251955, 251956);
Mycosphere Doi 10.5943/mycosphere/3/3/2

Vitobamba (USM 239436, 239441, 239443, 239466, 239469, 239479, 239505, 251947); Cadena (USM 251963).

Notes - pantropical species (Núñez \& Ryvarden 2001).

\section{Phanerochaetaceae Jülich}

- Antrodiella semisupina (Berk. \& M.A. Curtis) Ryv.

Specimens examined - Culebrachayoc (USM 239459).

Notes - cosmopolitan species (Núñez \& Ryvarden 2001).

- Flaviporus hydrophilus (Berk. \& M.A. Curtis) Ryv.

Specimens examined - Quincemil (USM 239504, 251951); Vitobamba (USM 251968); Cadena (USM 251964).

Notes - neotropical species (Ryvarden \& Johansen 1980).

\section{Polyporaceae Fr. ex Corda}

- Coriolopsis caperata (Berk.) Murrill

Specimens examined: Quincemil (USM 239457); Vitobamba (USM 239442).

Notes - cosmopolitan species, common in the tropical and subtropical areas of America (Ryvarden \& Johansen 1980).

Earliella scabrosa (Pers.) Gilb. \& Ryvarden Specimen examined - Vitobamba (USM 239471).

Notes - pantropical species, common in the tropical and subtropical areas of America (Núñez \& Ryvarden 2001).

- Hexagonia hydnoides (Sw.) M. Fidalgo

Specimens examined - Quincemil (USM 239449).

Notes - pantropical species (Ryvarden \& Johansen 1980).

Lenzites elegans (Spreng.) Pat.

Specimens examined - Cadena (USM 239472).

Notes - pantropical species (Núñez \& Ryvarden 2001).

- Perenniporia martia (Berk.) Ryvarden 
Specimens examined - Culebrachayoc (USM 239460).

Notes - pantropical species (Núñez \& Ryvarden 2001).

- Polyporus dictyopus Mont.

Specimens examined - Vitobamba (USM 239470, 239492 as P. aff. dyctiopus).

Notes - pantropical species (Núñez \& Ryvarden 2001).

\section{- Polyporus grammocephalus Berk.}

Specimens examined - Vitobamba (USM 239462, 239438 as $P$. aff. grammocephalus).

Notes - pantropical species (Núñez \& Ryvarden 2001).

\section{- Polyporus leprieurii Mont.}

Specimens examined - Quincemil (USM 251953， 251954， 251958) Vitobamba (USM2 39438, 239478, 251948); Cadena (USM 251962); Culebrachayoc (USM 251959).

Notes - neotropical species (Núñez \& Ryvarden 2001).

- Polyporus tenuiculus (Beauv.) Fr.

Specimens examined - Vitobamba (USM 239473); Quincemil (USM 239489, 239493).

Notes - pantropical species (Núñez \& Ryvarden 2001).

\section{- Polyporus tricholoma Mont.}

Specimens examined - Quincemil (USM 239474); Culebrachayoc (USM 239463 as P. aff. tricholoma).

Notes - pantropical species (Gilbertson \& Ryvarden 1987).

\section{- Pycnoporus sanguineus (L.) Murrill}

Specimens examined - Quincemil (USM 251957); Vitobamba (USM 239475); Culebrachayoc (USM 251960).

Notes - pantropical species (Núñez \& Ryvarden 2001).

- Tinctoporellus epimiltinus (Berk. \&

Broome) Ryvarden

Specimens examined - Quincemil (USM 239490).
Notes - pantropical species (Núñez \& Ryvarden 2001).

- Trametes versicolor (L.) Lloyd

Specimens examined - Quincemil (USM 239444, 239465, 239486, 239494).

Notes - cosmopolitan species (Núñez \& Ryvarden 2001).

- Trametes villosa (Sw.) Kreisel

Specimens examined - Culebrachayoc (USM 239496).

Notes - pantropical species (Gilbertson \& Ryvarden 1987).

Tyromyces leucomallus (Sw.) Kreisel

Specimens examined - Cadena (USM 239455).

Notes - cosmopolitan species (Núñez \& Ryvarden 2001).

\section{Acknowledgements}

We would like to thank Dra. Maria Alice Neves (UFSC/Brazil) and Dr. Gerado Lucio Robledo (UNC/Argentina) for their valuable contribution. Field and herbarium research was made possible by grant \#0717453 of the US National Science Foundation. We thank Renan Valega, Pedro Centeno, Jason Wells, and Fernando Farro for support and assistance during field and herbarium research. Lastly, we thank Consejo Nacional de Ciencia, Tecnología e Innovación Tecnológica (CONCYTEC) for financial support and the Coordenação de Aperfeiçoamento Pessoal de Nível Superior (CAPES) for provided a postdoctoral fellowship (CAPES/REUNI/UFSC) to the last author. This work is part of project "Diversidad $\mathrm{y}$ aspectos ecológicos de los hongos lignolíticos del Perú - PolíporosPERU" (Depto. Botânica/UFSC nº 2011.1023).

\section{References}

Corner EJH. 1983 - Ad Polyporaceae I. Beihefte zur Nova Hedwigia 75, 1-182.

Decock C, Herrera-Figueroa S. 2007 - Studies in Ganodermataceae (Basidiomycota): the concept of Ganoderma coffeatum in the Neotropics and East Asia. Cryptogamie, Mycologie 28, 77-89.

Furtado JS. 1967 - Some tropical species of 
Ganoderma (Polyporaceae) with pale context. Persoonia 4, 379-389.

Furtado JS. 1981 - Taxonomy of Amauroderma (Basidiomycetes, Polyporaceae). Memoirs of the New York Botanical Garden 34, $1-109$.

Gilbertson RL, Ryvarden L 1987 - North American Polypores, Vol. II. Oslo, Fungiflora, 438-885.

Hibbett DS, Binder M, Bischoff JF, Blackwell M, Cannon PF, Eriksson OE, Huhndorf S, James T, Kirk PM, Lücking R, Lumbsch HT, Lutzoni F, Matheny PB, Mclaughlin DJ, Powell MJ, Redhead S, Schoch CL, Spatafora JW, Stalpers JA, Vilgalys R, Aime MC, Aptroot A, Bauer R, Begerow D, Benny GL, Castlebury LA, Crous PW, Yu-Cheng Dai, Gams W, Geiser DM, Griffith GW, Gueidan C, Hawksworth DL, Hestmark G, Hosaka $\mathrm{K}$, Humber RA, Hyde KD, Ironside JE, Koljalg U, Krutzman CP, Karl-Henrik Larsson, Lichtwardt R, Longcore J, Miadlikowska J, Miller A, Moncalvo JM, Mozley-Standridge S, Oberwinkler F, Parmasto E, Reeb V, Rogers JD, Roux C, Ryvarden L, Sampaio JP, Schümbler A, Sugiyama J, Thorn RG, Tibell L, Untereiner WA, Walker Ch, Wang Z, Weir A, Weiss M, White MM, Winka K, Yi-Jian Yao, Zhang N. 2007 - A higher-level phylogenetic classification of the Fungi. Mycological Research 111, 509-547.

Larsen MJ, Cobb-Poulle LA. 1990 - Phellinus (Hymenochaetaceae): a survey of the world taxa. Synopsis Fungorum 3, 1206.

Núñez M. 1996 - Fructification of Polyporaceae s.l. (Basidiomycota) along a gradient of altitude and humidity in the Guanacaste Conservation Area (Costa Rica). Journal of Tropical Ecology 12, 893-898.

Núñez M, Ryvarden L. 2000 - East Asian Polypores. Vol. 1. Ganodermataceae and Hymenochaetaceae. Synopsis Fungorum 13, 1-169.

Núñez M, Ryvarden L. 2001 - East Asian Polypores. Vol. 2. Polyporaceae s.l. Synopsis Fungorum 14, 170-522.

Ryvarden L. 1991 - Genera of Polypores. Nomenclature and taxonomy. Synopsis Fungorum 5, 1-363.

Ryvarden L. 2000 - Studies in neotropical polypores 2: a preliminary key to neotropical species of Ganoderma with a laccate pileus. Mycologia 92, 180-191.

Ryvarden L. 2004 - Neotropical polypores. Part 1. Synopsis Fungorum 19, 1-229.

Ryvarden L, Johansen I. 1980 - A preliminary polypore flora of East Africa. Oslo, Fungiflora, 1-636.

Steyaert RL. 1972 - Species of Ganoderma and related genera mainly of the Bogor and Leiden herbaria. Persoonia 7, 39-70.

Zelski SE, Raja HA, Miller AN, Shearer CA. 2011 - Chaetorostrum quincemilensis, gen. et sp. nov., a new freshwater ascomycete and its Taeniolella-like anamorph from Peru. Mycosphere 2, 593-600. Doi 10.5943/mycosphere/2/5/9. 